\title{
LEGAL FRAMEWORK ON GREEN BUILDING IN INDONESIA AND THE ALTERNATIVE POLICY
}

(Kerangka Hukum Bangunan Hijau di Indonesia dan Alternatif Kebijakan Untuk Mengembangkannya)

\author{
Wuri Virgayanti \\ Kantor Wilayah Kementerian Hukum dan Hak Asasi Manusia Jawa Barat \\ Jalan Jakarta Nomor 27, Bandung \\ Email:wvirgayanti@gmail.com
}

Naskah diterima: 8 Mei 2017; revisi: 2 Agustus 2017; disetujui: 4 Agustus 2017

\begin{abstract}
Abstrak
Bangunan gedung merupakan sektor yang mengkonsumsi energi cukup tinggi di seluruh dunia. Dibutuhkan regulasi dan kebijakan yang tepat untuk membantu sektor tersebut mengurangi tingkat konsumsi energinya. Sebagai reaksi terhadap kebutuhan ini, konsep bangunan hijau banyak diterapkan oleh banyak negara termasuk Indonesia sebagai alternatif konsep bangunan tradisional. Namun demikian, implementasi konsep ini dirasakan cukup lambat, khususnya di Indonesia. Dari sudut pandang hukum, makalah ini bertujuan untuk menjawab mengapa sektor bangunan hijau di Indonesia tidak berkembang dengan baik. Metode yang digunakan dalam penelitian ini adalah penelitian hukum normatif. Hasil analisis menemukan bahwa pergerakan yang lamban di sektor bangunan hijau disebabkan oleh lemahnya kerangka regulasi yang ada serta minimnya kebijakan pemerintah dalam menstimulus pasar untuk membangun bangunan hijau baik di level pusat maupun daerah. Dengan demikian, harus ada peraturan perundang-undangan yang dapat menjadi landasan yang cukup kuat bagi perkembangan bangunan hijau di Indonesia. Selain itu juga harus ada kebijakan pemerintah untuk mendorong tercapainya amanat dari peraturan perundang-undangan tersebut.

Kata Kunci: bangunan hijau, perangkat tolak ukur bangunan hijau, analisa daur hidup
\end{abstract}

\begin{abstract}
As buildings are one of the highest energy consumers from all over the world, there is special need to focus on how to mitigate energy consumption through regulation and policy. Responding this necessity, the concept of green building is being implemented in many countries along with Indonesia as an alternate to the traditional building concept. However there is slow movement in implementing this concept, especially in Indonesia. From legal viewpoint this paper will aim to answer why the Indonesian green building sector is not well developed. The method used in this paper is normative legal research. The analysis finds that the slow movement is due to the lack of the regulatory framework on its subject. Moreover, there is only little support from the government toward policies that might drive growth of the green building development. In light of this, there should be robust and strong regulatio. This can be achieved at the national level by regulating green buildings and also having government policies that encourage the development of green buildings.
\end{abstract}

Keywords: green building, green building rating tool system, life cycle analysis 


\section{A. Introduction}

As an international movement, "green building" emerged in the early 1990s and has now developed globally. Because of this, it has inevitably influenced Indonesia as one of the developing countries. However, compared to other countries Indonesia is quite late to the green building movement. Compared to Malaysia and Singapore as the member of the ASEAN, Indonesia is far behind these countries. In 2005, Singapore launched its green building rating tool system named Green Mark Scheme, while it was not until 2010 when Indonesia implemented green building criteria within the infrastructure development. The green building rating tool GREENSHIP was introduced by the Green Building Council of Indonesia $(G B C l)$ in 2010. Meanwhile there are only three regulations that regulate the green building in Indonesia of which 2 regulations are on national level and the other regulation is set up under the local government authority. Those regulations are The Ministry of Environmental Decree Number 8 Year 2010 on Criteria and Certification of Eco-friendly Building, The Regulation of the Minister of Public Works and Public Housing No. 02/PRT/M/2015 on Green Building and The Governor of Jakarta Decree Number 38 Years 2012 on Green Building.

One of the important reasons underlying the establishment of green building rating tools and its regulation in Indonesia is due to climate change mitigation action. In 2009, the World Business Council for Sustainable Development stated most countries building stock is responsible for not only $40 \%$ of energy consumption and generating a massive amount of greenhouse, but also for the great amount of water consumption. Furthermore, the pollution generated from either the construction or operation of buildings should also be taken into account. ${ }^{1}$ In other words, buildings are both a major user of energy and greenhouse gas emitters. $^{2}$

In addition to climate change mitigation action, the establishment of green building rating tool in Indonesia is to also actualize the sustainable building concept consistently. This is paramount since by applying the green building concept, there are a lot of potential environmental, economic, financial and social benefits that can be taken. ${ }^{3}$ For example, by implementing the green building concept not only the building operating cost, resource consumption and waste also can be reduced. This also has a positive flow on effect as it may improve the working and living quality of the occupants. ${ }^{4}$ Furthermore, there is evidence from United State that tenants have moved from conventional buildings to buildings certified under the Leadership in Energy and Environmental Design (LEED) ${ }^{5}$. This is due to

1 Bao Xia et al, "Green Star Points Obtained by Australian Building Project" Journal of Architectural Engineering (2013): 302.

2 Catalina Spataru et al, "Domestic Energy and Occupancy: A Novel Post-Occupancy Evaluation Study", International Journal of Low Carbon Technologies 5 (2010): 148.

3 Bao Xia et al, loc.cit.

4 G. Christopher Wedding and Douglas Crawford-Brown, "Measuring Site-Level Success In Brownfield Redevelopments: A Focus On Sustainability And Green Building," Journal of Environmental Management 85 (2007): 483.

5 Leadership in Energy and Environmental Design or LEED is an established and widely used green building rating system in the United State and managed by the United State's Green Building Council. 
the understanding it may improve health and productivity $^{6}$ resulting from the improved indoor environmental quality because of the green building.

However, the implementation of the green building concept and especially the green building rating-tool is very slow in Indonesia. Testament to this is the total number of the green buildings that actually exist in Indonesia. To date there are only 8 green buildings certified under the GREENSHIP. ${ }^{7}$ Comparing that figure to Singapore who in 8 years after having it applied there, have more than 1,500 buildings certified under the Green Mark. ${ }^{8}$ Furthermore, in Malaysia after 3 years of its application, there are approximately 100 buildings certified under the Green Building Index. ${ }^{9}$ Based on the background, this paper is trying to answer the reason behind the slowly improvement on Indonesian green building development.

\section{B. Research Method}

Method used in this research is normative legal research with descriptive approach. This study is based on secondary data availability. Secondary data obtained through library research by using sources in the form of legislation, books, journals and articles. The analytical methods used in this research are qualitative analysis.

\section{Analysis}

\section{Indonesian Green Building Legal Framework}

\section{a. Regulation on Green Building and Its Challenges}

In 2009 at the G-20 Summit forum held in Pittsburg, a 26\% target of carbon emission reduction was determined to be achieved in Indonesia by 2020 and also up to $41 \%$ with international help. ${ }^{10}$ One of the focuses on reducing the carbon emission is in the construction area since it contributes major amount of carbon. ${ }^{11}$ More than $60 \%$ of gasses generated by the construction industries consist of $\mathrm{CO}_{2}, \mathrm{SO}_{2}$ and methane gas. ${ }^{12}$ Furthermore the building sector is known as the substantial of energy user. Based on data released by the United State Energy Information Agency, energy consumption in Indonesia increased by $44 \%$ in the period of 2002 to $2012^{13}$ and is likely to increase for $9 \%$ by 2019 . Additionally, according to the Agency for the Assessment and Application of Technology (BPPT) Indonesia's energy consumption in 2000 could be separated into sectors such as residential, industry,

6 Amanjeet Sighn et all, "Effects of Green Buildings on Employee Health and Productivity,"International Journal Low Carbon and Technology 3 (2010): 1665.

7 Baru 8 Gedung Ini Berkonsep Green Building, Jakarta, Thursday $2^{\text {nd }}$ May 2013 available in http://www.gatra. com/nusantara-1/nasional-1/29575-di-indonesia-baru-8-gedung-berkonsep- green-building,-apa-saja.html.

8 Sahid Mochtar dan Dewi Larasati, "Comparative Study on Green Criteria Development Towards Sustainable Infrastructure In Indonesia" Society For Social Management Systems Internet Journal 12 (2001): 2.

9 Ibid.

10 Bagoes Wiryomartono, "Green Building and Sustainable Development Policy in Indonesia since 2004," International Journal of Sustainable Building Technology and Urban Development 2, (2015): 82.

11 Njo Anastasia, "The Way to Encourage Green Building in Indonesia," (The paper was presented at AsRES International Conference, Kyoto, Japan, 2013) 2.

12 Ibid, 3.

13 Bagoes Wiryomartono, loc.cit. 
transport, commercial and other sectors. They consume around $38.8 \%, 36.5 \%, 18.2 \%$, $2.7 \%$, and $3.8 \%$ respectively. ${ }^{14}$ In general total energy consumption for the built environment was around $78 \%$ of total energy consumption in 2000. ${ }^{15}$ The energy consumption in the built environment is mainly as a result of air conditioning and lighting systems. ${ }^{16}$

Therefore in order to achieve the goal of reducing emissions (particularly in built environmental sector) and to actualize the green building principles, the government issued several regulations related to buildings. At the national level there are two regulations namely the Ministry of Environment Decree Number 08 Year 2010 on Criteria and Certification of Eco-friendly Building and the Regulation of the Minister of Public Works and Public Housing No. 02/PRT/M/2015 on Green Building. However these regulations are not considered sufficient enough to support the development of green buildings in Indonesia since Law Number 12 Year 2011 on Legislation Drafting to some extent make the ministerial decree legal standing unclear. Consequently, the binding effect of this kind of regulation to the local governments is ambiguous and debatable.

Article 7 Paragraph (1) of Law Number 12 Year 2011 on Legislation Drafting, the hierarchy of regulations in Indonesia is: ${ }^{17}$

1. The Constitution of The Republic Indonesia Year 1945;
2. The Provision of People's Consultative Assembly

3. Law/ Government Regulation In Lieu of Law;

4. Government Regulations;

5. Presidential Decree;

6. Provincial Regulations; and

7. District Regulations.

Additionally, Article 7 Paragraph 2 contends the legal force of these legislations in accordance with the hierarchy as referred to in article 7 Paragraph (1). ${ }^{18}$

Based on Article 7 paragraph (1) and (2), it can be seen that the ministerial decree is not included in this hierarchy of legislation. Yet this is mentioned in Article 8 Paragraph (1) of the Legislation Drafting Law. This article asserts the types of legislation apart as referred to in Article 7 Paragraph 1 is including the regulation set by the minister. The legal binding force of this regulation is recognized as long as it is formed based on the order of higher legislation, or in accordance with the authority of the institution/body. From this provision there are two requirements for legislation to have the binding force. These being formed based on the order of higher legislation, or in accordance with the authority of the organ. However in legal doctrine it is only known as two kinds of legislation based on basic authority of its formation. These being the legislation formed on the basis of the attribution and the legislation formed on the basis of delegation. ${ }^{19}$

\footnotetext{
Ibid.

Ibid.

Ibid.

The Law Number 12 Year 2011 on Legislation Drafting, Article 7 Paragraph 1.

The Law Number 12 Year 2011 on Legislation Drafting, Article 7 Paragraph 2.

A. Hamid S. Attamimi, Peranan Keputusan Presiden Republik Indonesia Dalam Penyelenggaraan Pemerintahan Negara : Suatu Studi Analisis Mengenai Keputusan Presiden Yang Berfungsi Pengaturan Dalam Kurun Waktu Pelita I - Pelita VI, Dissertasi, Pasca Sarjana Universitas Indonesia, 1990: 352.
} 
The attribution is defined as the creation of the authority of a new legislation by the Constitution or by the legislators to a state organ, either that already existing or newly formed for a certain purpose.${ }^{20}$ For instance, the attribution legislation in the Indonesian Constitution is including Law, Government Legislation in Lieu of Law, Government Regulation and Local Regulation. Meanwhile delegation in the legislation framework is defined as the transfer of the authority to establish rules from delegator to delegate and the responsibility to implement this delegation is fully in the delegate hands, while the responsibility of the delegator is limited. ${ }^{21}$ An example of this is when the law orders to further regulate a matter into ministerial decree. The ministerial decree is then formed based on the order of the higher legislation and is categorized as the delegated legislation.

In fact, the Regulation of the Minister of Public Works and Public Housing on Green Building is not formed under the attribution or delegation basis. It is formed based on the rule of the Article 8 Paragraph 2 of the Law on Hierarchy of Legislation, which for some scholars the legal standing of this regulation is contentious. There is a need to further study especially related to the hierarchical characteristic of legislation as the legal norm where the lower legislation will always find its validity to the higher legislation. ${ }^{22}$ Besides, in order to support the green building development in Indonesia, there is a need to establish a stronger regulation such as Law on Green Building which is applied nationally and has stronger legal force than ministerial decree.

Furthermore, the Ministry of Environmental Decree on Criteria and Certification of Ecofriendly Building generally regulates the criteria of a green building and how to get a certification once the building fulfills these criteria. ${ }^{23}$ Besides, this ministerial decree regulates the institution who gives a certificate of eco friendly building or green building and also regulates that the certification body should be a legal entity, have a quality management system, include controls for the use of certificates and have energy assessors who are competent in the field of green buildings environment. ${ }^{24}$ Presently, the only certification body that exists in Indonesia is the $\mathrm{GBCl}$. They established three rating tools called GREENSHIP New Building which was launched in 2010, GREENSHIP Existing Building launched in 2011 and GREENSHIP Interior Space launched in 2012.

If fact, even the $\mathrm{GBCl}$ already release these rating tool systems, until recently there are only 8 buildings that are certified under the GREENSHIP rating tool system. ${ }^{25}$ Compared to other countries in Asia, such as Singapore and Malaysia, the achievements of $\mathrm{GBCl}$ in Indonesia are relatively low which may be due to the weak legal support for the $\mathrm{GBCl}$. It appears $\mathrm{GBCl}$ does not have nationwide legal

20 Ibid.

21 Ibid.

22 Hans Kelsen, cited in Jimly Asshiddiqie \& M. Ali Safa'at, Teori Hans Kelsen Tentang Hukum Konpress, Jakarta, 2006, page 157.

23 The Ministry of Environmental Decree Number 08 Year 2010 on Criteria and Certification of Eco-friendly Building, Article 3.

24 The Ministry of Environmental Decree Number 08 Year 2010 on Criteria and Certification of Eco-friendly Building, Article 6.

25 See 'Baru 8 Gedung Ini Berkonsep Green Building'. 
support or the legitimacy as an independent body to release building permits toward the GREENSHIP mechanism. ${ }^{26}$ There is no support from the higher legislation such as Law or Government Regulation, since support by the Ministry Decree is not strong enough to back up the implementation of GREENSHIP rating tool in Indonesia. In many other countries those kinds of institutions are built and supported by Law or Government Regulation. ${ }^{27}$

Compared to the Ministry of Environmental Decree on Criteria and Certification of Ecofriendly Building, the content of the Regulation of the Minister of Public Works and Public Housing on Green Building is more complex. There is much scope of the later regulation which includes the principle of green building, the types of buildings that bear the requirements of green building, green building requirements, certification, incentives for implementation of green buildings and the role of the community. ${ }^{28}$ However this regulation seems unimplemented by local governments to give the authority permitting the development of building in their areas. This has happened since there is no higher legislation that binds the local governments to implement this regulation. There is no legal consequence if the local governments are not applying it. The general Law number 28 of 2002 on Building also does not regulate anything related to the green buildings. This law only regulates some requirements related to the development of a building in a 'traditional' way. ${ }^{29}$

Moreover when looking further into existing legislations including the Building Law and the Law number 23 of 2014 on Local Government (Local Government Law), the local government has an authority to regulate buildings and any permit that is associated with it. This can be seen in article 35 Paragraph 4 of the Building Law. This article mentions 'Construction of buildings can be carried out after the technical plan of the building was approved by the Local Government in the form of building permits, except for the special function buildings'.30 Meanwhile according to the Local Government Law which embraces the local autonomy principle, the local government is responsible for the concurrent government affair given by this law. ${ }^{31}$ The concurrent government affairs consist of mandatory and optional affairs ${ }^{32}$, where buildings are categorized as basic service under the mandatory affairs ${ }^{33}$ and local government has authority to grant the building permits and certificate of building feasible function. $^{34}$

Regarding the local level, there is only one regulation applying to green building which belongs to the Jakarta Capital Region namely

Bagoes Wiryomartono, Op.cit, 84.

Ibid.

28 The Regulation of the Minister of Public Works and Public Housing No. 02/PRT/M/2015 on Green Building, Article 3.

29 The Regulation of the Minister of Public Works and Public Housing No. 02/PRT/M/2015 on Green Building, Article 6.

30 The Law number 28 of 2002 on Building, Article 35 Paragraph 4.

31 The Law of Republic of Indonesia Number 23 of 2014 on Local Government, Article 9 Paragraph 4.

The Law of Republic of Indonesia Number 23 of 2014 on Local Government, Article 11 Paragraph 1.

33 The Law of Republic of Indonesia Number 23 of 2014 on Local Government, Article 11 Paragraph 1,2 and 3.

34 The Law of Republic of Indonesia Number 23 of 2014 on Local Government, Annex on The Division of Tasks in Building Sector Between the Central Government and Local Government. 
the Governor of Jakarta Decree Number 38 Years 2012 on Green Building. On paper this regulation appears quite complete, yet the supporting policies from national and local governments are needed to ensure regulation can be implemented and followed by other local governments.

\section{b. Legal Framework on Green Building In Jakarta Province}

As discussed previously, authority to grant permits in the building sector belongs to local governments. Hence the existence of local regulations in relation to green building is very necessary, especially when there is lack of legislation at the national level. This is intended to encourage the development of the green building in Indonesia under the certain legal framework. Generally speaking, the presence of local regulation on green building will be very importantin the waythat this regulation will assist the local government as the licensor on building construction in monitoring, enforcement and also creating regulatory policy related to the green building in their own territory. Despite the importance of local regulations for green buildings, so far only Jakarta Province has such regulation as seen in Governor of Jakarta Decree Number 38 Years 2012 on Green Building. The final objective the Governor of Jakarta Decree on Green Building is to achieve sustainable development, ${ }^{35}$ particularly by meeting the reduction target of energy consumption by $30 \%$ and water consumption by $20 \%$ compared to the consumption in conventional buildings. ${ }^{36}$

The Governor of Jakarta Decree on Green Building is a mandatory regulation that is subjected to all buildings located in Jakarta that fulfill some specific requirements. ${ }^{37}$ Since this is mandatory, this regulation should be implemented and enforced, whilst also having the ability to be revised when necessary as building development in Jakarta changes. ${ }^{38}$ This Governor Decree regulates some types of buildings namely office buildings, shopping centers and residential buildings with an area of more than 50,000 square meters. ${ }^{39}$ This is also used to manage the establishment of hotels and health facilities with an area of more than 20,000 square meters ${ }^{40}$ and educational facilities with more than 10,000 square meters in total. ${ }^{41}$ This regulation is applied not only to new buildings but also to buildings that are under construction as well as existing buildings. ${ }^{42}$ According to this regulation, green building criteria have been included as part of issuing of the green building permit. ${ }^{43}$

Based on data presented by the Jakarta Province ${ }^{44}, 3$ years after the Governor of Jakarta Decree on Green Building enacted, there are

\footnotetext{
The Governor of Jakarta Decree Number 38 Years 2012 on GreenBuilding, Article 2.

Bagoes Wiryomartono, Op.cit., 84.

37 Sahid Mochtar and Dewi Larasati, "Comparative Study On Green Criteria Development Towards Sustainable Infrastructure In Indonesia," (2014) Society for Social Management Internet Journal (2014): 2.

8 Ibid, 4.

39 The Governor of Jakarta Decree Number 38 Years 2012 on GreenBuilding, Article 3 Paragraph 3 (a), (b) and (c)

40 The Governor of Jakarta Decree Number 38 Years 2012 on GreenBuilding, Article 3 Paragraph 3 (d).

41 The Governor of Jakarta Decree Number 38 Years 2012 on GreenBuilding, Article 3 Paragraph 3 (g).

42 The Governor of Jakarta Decree Number 38 Years 2012 on GreenBuilding, Article 6 and Article 32.

43 The Governor of Jakarta Decree Number 38 Years 2012 on GreenBuilding, Article 2.

44 Pemprov DKI Jakarta Kukuhkan Posisi Sebagai Center of Exellence Bangunan Gedung Hijau, di unduh dari http://greenbuilding.jakarta.go.id/news/2016/12/14/pemprov-dki-jakarta-kukuhkan-posisi-sebagai-centerof-exellence-bangunan-gedung-hijau/, tanggal 13 Juli 2017.
} 
around 260 buildings with a total area of nearly 15 million square that is complied with this Governor Decree. This figure is equivalent to the total potential reduction of greenhouse gas effect to 605 thousand metric tons per year, the potential energy savings of more than 850 thousand MWh annually and electricity savings of up to US $\$ 68.3$ million.

Despite of the total number of the buildings that is already complied with the Governor Decree, energy saving and emission reduction achieved, this regulation is still considered as an ineffective tool to reduce the level of energy consumption and to actualize the sustainable development. ${ }^{45}$ There are some reasons why this regulation seems ineffective. Firstly, the scope of its implementation on the green building criteria is only applied to the new buildings development, while the criteria of the existing building not as tight as the new building criteria. Besides, there is no obligation for the existing buildings to be upgraded as green buildings, since there are hundreds of buildings built before this regulation was enacted. Secondly, this Governor Decree is only applied to some types of building with certain area and function. In fact, there is no obligation for buildings which the area is below than the area set forth in the Governor Decree. Thus, these considerations should be integrated in the amendment of this Governor Decree in order to enhance its effectiveness in regulating green building in Jakarta Province.
In additions, since this regulation is categorized as control and command based regulation, limitation exists related to the nature of its characteristics, accordingly the implementation of this regulation may be inappropriate. It is said that even though the command and control based regulation is successful in bringing a better practice in the environmental protection, this approach may not be the best solution to address modern environmental problems. ${ }^{46}$ The categorization of the Governor of Jakarta Decree on Green Building as a control and command based regulation relies on fact that this regulation consists of standard setting that should be followed and prohibit certain forms of actions by giving a sanction or punishment. ${ }^{47}$ To some extent the command and sanction given in this regulation seems unable to make people obey the regulation. In fact the effectiveness of this regulation is hard to be achieved especially related to the enforcement. When it comes to the enforcement, the main question is how much of those resources or funds are owned by the government, especially since enforcement is expensive. ${ }^{48}$ Moreover the method used to prove the contention and the impact of the enforcement is vague. ${ }^{49}$ Hence in order to achieve its objective, there should be an alternative strategy given in this regulation, such as moving toward an incentive-based approach rather than a disciplinarian one. ${ }^{50}$

\footnotetext{
$45 \quad$ Bagoes Wiryomartono, Op.cit., 83.

46 Lauren E. Glesby, "Fitting the Bill-Proposed Regulatory and Non-Regulatory Approaches to Advancing Green Building Technologies," Fordham Environmental Law Reviews 21 (2010): 647.

47 Robert Baldwin, Martin Cave and Martin Lodge, Understanding Regulation, Theory, Strategy and Practice (Oxford University Press, $2^{\text {nd }}$ edition, 2012), page 106.

48 Ibid.

49 Ibid.

50 Ibid.
} 


\section{Tax Incentives for the Development of Green Building Industry}

Asanalternative to extremelystrictcommand and control based regulation, incentivebased approach could be implemented. As per the later approach, those who pollute the environment can be encouraged to obey the regulation by imposing negative or positive taxes or by providing grant or subsidy from the government budget. ${ }^{51}$ In the Indonesian green building case, the most appropriate method under the incentive-based approach is to promote the green buildings development by providing positive taxes or tax incentives. This is based on the fact that the method is the least expensive way to be achieved and it can be done by government rather than subsidy or grant. Moreover this is important for the developers, constructors or the owners of the building since they could get direct benefit from the reduction of the tax that should be paid.

A tax incentive is a policy released by the government to lower a person tax obligation either by reducing its payable amount (credit reduce) or by reducing a percentage of the tax that should be paid (tax deduction). ${ }^{52}$ The tax incentive policy is seen as important not only for new buildings, but also especially for the existing buildings. This is due to energy efficiency in existing is responsible for a significant amount of greenhouse gas emissions that are generated primary from the energy consumption for heating, cooling, lighting and the operation of electrical equipment. ${ }^{53}$ By giving the building owners a tax incentive, the possibility of them applying the green building criteria is bigger rather than without this incentive. Furthermore for governments this kind of incentive also helps to cut the total number of greenhouse gas emissions. A report released by IPCC estimates that there is a possibility to reduce more or less $29 \%$ of the total of global GHG emission. ${ }^{54}$ Other benefits apart from emission reduction might also be increasing energy security, improving health for the occupants and ensuring achievement of other objective sustainable development. ${ }^{55}$

In US policy scheme, the tax reduce mechanism is considered more valuable than the tax deducted mechanism. ${ }^{56}$ The example of the tax incentive given by the United State federal government is contained in the Emergency Economic Stabilization Act of 2008 (EESA) that revise the Energy Policy Act of $2005 .{ }^{57}$ In the EESA, tax incentives related to the commercial building is regulated under section 179D. Originally, owners of the building are required to capitalize all of the costs released by a building including the cost of building improvement or retrofits and than depreciate the total cost over 39 years. ${ }^{58}$ However under

\footnotetext{
Ibid.

52 Michael J Zimmer and Jennifer M Rohleder “Green Building Financing” in J. Cullen Howe and Michael B. Gerrarad, The Law of Green Buildings, Regulatory and Legal Issues in Design, Construction, Operations, and Financing (American Bar Association and ELI Press) page 107.

53 Thomas Garry, "Turning Buildings Green: Instruments for Improving the Energy Performance of Existing Buildings," New Zealand Journal of Environmental Law 2 (1) (2008): 234.

56 Michael J Zimmer and Jennifer MRohleder, Op.cit., 107.

$58 \quad$ Ibid, 108.
}

54 Ibid.

55 Ibid.

57 Ibid. 
section 179D, owners of the building are allowed to deduct certain costs resulted from the energy efficiency rather than capitalize it. Therefore the cost recovery could be gained faster than compared to cost recovery of a building that is not benefiting from the tax incentive. ${ }^{59}$

The tax incentive applied by the US Federal government could be a good policy to encourage the development of green building in Indonesia, especially since the tax incentive scheme applied by the United State Federal Government is considered more equitable for the green building owners. In other words, the more they reduce their emission the more they may get the tax reduction. However, until recently there has been no such tax incentive applied in Indonesia. So far incentives provided by the government for green buildings owners and or managers are simply related to the administrative such as licensing facility ${ }^{60}$ and promotion or publication ${ }^{61}$ and also in the form of technical assistance for green building pilot project. ${ }^{62}$ The only financial benefit is in the form of levy licensing relief and service fee waiver. ${ }^{63}$

\section{The Application of Green Building Rating Tool System and Life Cycle Analysis as the Driver of the Green Building Development}

\section{a. Green Building Rating Tool System}

Besides the robust and certain legal framework, the development of green buildings should also be supported by government policy. One of the ways is to encourage industries to comply with the green building rating tool system. Even though the green building rating tool system in Indonesia has not been supported by a proper legislation, the application of the green building rating tool system might help to encourage the industries comply with the criteria and could give benefit for the government as well.

It is realized that the intention of the building constructors to implement the green building rating tool criteria varies between one and the other. Some developers apply these rating tools criteria merely because of environmental reasons, but the majority of developers do it because of the financial advantages. ${ }^{64}$ This is due to the consideration that these systems related to energy saving by applying the standard of green construction features such as solar heating, natural lighting, reduce water and energy used might assist in gaining economic benefits. ${ }^{65}$ These green features

Ibid.

60 The Regulation of the Minister of Public Works and Public Housing No. 02/PRT/M/2015 on Green Building, Article 28, Paragraph 3.

61 The Regulation of the Minister of Public Works and Public Housing No. 02/PRT/M/2015 on Green Building, Article 28, Paragraph 3.

62 The Regulation of the Minister of Public Works and Public Housing No. 02/PRT/M/2015 on Green Building, Article 28, Paragraph 3.

63 The Regulation of the Minister of Public Works and Public Housing No. 02/PRT/M/2015 on Green Building, Article 28, Paragraph 4.

64 Eileen P. Kelly et all, "Managerial and legal Perspective on the Green Building Movement," Journal of Legal, Ethical and Regulatory Issues 13 (2) (2010): 74.

65 Ibid. 
are very important since they are seen as the marketing tools, or in other words they are used as a foundation to charge a higher price to the customers. ${ }^{66}$ In this sense, the developers are depending on the good public perception and public trust to be able to sell more of their product.

For the government, the benefit that might be taken if there are more users of the green building rating tool systems is that these systems support the government objective in achieving sustainable development and climate change mitigation as mentioned in some legislations. Besides, these systems might help the government to cover its shortfall in the licensing system where generally there is only limited green building expertise in the government office. In addition, these systems might also facilitate the government's performance in monitoring and evaluation because of the assistance from independent professional institutions.

Some of the standards set in the green building rating tool system that might be applied in Indonesia are the energy efficiency approach in new building and life cycle analysis (LCA). Globally the construction sector and building maintenance consume not only $40 \%$ of a total amount of world's energy, but also $65 \%$ of all electricity and raw materials. ${ }^{67}$ Consequently this is important for the government to issue policies that support energy efficiency. The primary principle of the energy efficiency in a building is to consume less energy for cooling, heating and lighting without reducing the amenities of the people who use the building. ${ }^{68}$

Some benefits could be taken as a result of the energy efficiency namely reducing the consumption of fossil fuel, minimizing the lifecycle cost and environmental impact, improving the indoor environment and increasing the productivity of those who work in the building. ${ }^{69}$

Logically, it is more cost-effective to integrate the energy efficiency strategy into the design of new building rather than to upgrade the existing building since a new building provides flexibility in measurement criteria. ${ }^{70}$ Some strategies that might be applied in the new building design including integrated design and passive design.

In integrated designapproach, the developers could choose energy saving elements. ${ }^{71}$ For example, they could use special glass windows that might allow the daylight without increasing the indoor temperature. Also heating systems that consume less energy, efficient ventilation and air conditioning options. ${ }^{72}$ However, to achieve the maximum energy efficiency, all these elements should be integrated with structural characteristic of the building and natural environment where the building exist. ${ }^{73}$ On the other words, since building is a complex system, all these elements should work together to achieve the best perform of energy saving.

66 Ibid.

67 Jesse W. Abair, “Green Buildings: What It Means To Be "Green" and the Evolution of Green Building Laws," Urban Lawyer 40 (3) (2008): 1.

68 Wen Hong et all, Building Energy Efficiency, Why Green BuildingAre Key to Asia Future (Asia Business Council, Hong Kong 2007) page 30.

69 Ibid, 31.

70 Ibid.

71 Ibid, 36.

72 Ibid.

73 Ibid. 
In order to encourage the integrated design by the developer some Countries are using LEED rating system. The LEED rating system is a voluntary rating system that governed by USGBC to evaluate the building environmental performance over its lifetime. ${ }^{74}$ Meanwhile the LEED International Roundtable consists of representatives of 21 countries and each of them applies LEED rating system that have already adjusted with their local condition. ${ }^{75}$ In addition so far LEED has been registered projects in 133 countries. ${ }^{76}$ In the United State LEED is leading in the market of commercial buildings with $90 \%$ of commercial buildings being certified under the LEED rating system. ${ }^{77}$

Besides its popularity, there are challenges facing the LEED rating tool system. Some scholars think that the LEED program is not run by the rating system, yet it is considered as a checklist of requirements to guarantee the performance of the green buildings. ${ }^{78}$ As a result a question around the effectiveness of the LEED program in reducing energy consumption and improving energy often occurs. ${ }^{79}$ However some studies prove that the LEED program helps reducing energy consumption and also increasing energy performance. For example in the Cascadia Region of the United States, in 2006 Turner researched the performance of 11 buildings and found that their performance was better than conventional buildings. ${ }^{80}$ Also in 2008, Fowler and Rauch examined 12 Federal Buildings which designed based on energy saving strategy and found that these building saved around 25$30 \%$ of energy consumption compared to the conventional commercial building in the United States. ${ }^{81}$

Besides the integrated design, passive design also has an important role in energy efficiency approach in green building. Generally passive design could be defined as design that takes benefit from natural energy flows to maintain the comfort temperature inside the building, whilst decreasing the dependency on mechanical heating and cooling. ${ }^{82}$ This design is very popular in European countries. Some standards that used in Europe among others are German Passivhaus, the British Code for Sustainable Homes and BREEAM. ${ }^{83}$

The Passivhaus standard is known as a leading standard in Europe by certifying around 25.000 projects in Europe. It rules that building should be designed as much as possible to reduce the using of energy for heating and cooling. In order to achieve this goal, a building design should include a high performance level of insulation

74 Arijit Sinha, Rakesh Gupta and Andreja Kutnar, "Sustainable Development and Green Buildings" Drvna Industrija 64 (1) (2014): 48.

75 Ibid.

76 Ibid.

77 Ibid.

78 Ibid, 49.

79 Ibid.

80 C. Turner, "LEED Building Performance in the Cascadia Region: A Post Occupancy Evaluation Report," http:// www.usgbc.org, 2006, it was accessed on $26^{\text {th }}$ April 2016.

81 K.M. Fowler and E.M Rauch, Assessing Green Building Performance: A Post Occupancy Evaluation of 12 GSA Buildings (Pacific Northwest National Laboratory Report Number PNNL- 17393, 2008).

82 Wen Hong et all, Op.cit., 49.

83 Angeliki Kylili and Paris A. Fokaides, “European Smart Cities: The Role ofZero Energy Building," Sustainable Cities and Society 15 (2005): 88. 
and ventilation system to keep the loss of the heat inside the building so that traditional heating and cooling systems become less important. ${ }^{84}$ The implementation of Passivhaus system in a tropical country such as Indonesia at first is questionable due to being originally designed for the application in European countries that have a different climate, ${ }^{85}$ however the newest revision of the Passivhaus standard has been included requirements for the Mediterranean region also. ${ }^{86}$

\section{b. Life Cycle Analysis}

Until recently, the notion that the green building development requires a higher cost than the conventional building is a drawback for the green building development. ${ }^{87}$ Thus there should be a measurement tool to calculate all the costs generated that relate to the building lifecycle and the aggregate benefit to society. One of the tools mentioned is Life Cycle Analysis (LSA). LCA is a comprehensive approach in examining the whole impact of a building to the environment. Its purpose is to quantify the energy and material flows generated from every phase of the building life cycle. ${ }^{88}$ This approach is used as 'a basic analysis for many performancebased sustainability design approach'. ${ }^{89}$ The application of the LCA to a new design could give not only a clear calculation of a current energy used but also calculation of long-term energy used, environmental and social impact. ${ }^{90}$

By using the tool, it is expected that building developers interested in developing the green building rather than the conventional one, will see the actual cost. Furthermore the chance to reduce the energy consumption is bigger than without applying this tool. For example, as a building consumes most of its energy during its service life, which is about $90 \%$ of its total life cycle energy generated, ${ }^{91}$ the decision in an appropriate design is needed during the preconstruction phase and LCA may inform the developers to choose the right design before building commences.

\section{Conclusion}

In conclusion, the slow development of green buildings in Indonesia is greatly impeded by the lack of legal framework in green building sectors. A Law in national level is needed to regulate the green building so that the local government could use it as a strong legal basis to create a local regulation in green building. In addition, some policies could be adopted by the government to encourage the building industries to build more green buildings such as the tax incentives, the implementation of green building rating tool system especially by implementing the integrated and Passivhauss

\footnotetext{
Ibid.

Ibid.

Ibid.

7 Queena K. Qian and Edwin H.W. Chan, “Government Measures Needed to Promote Building Energy Efficiency (BEE) in China" Facilities 28 (11/12) (2010): 568.

88 Sarah V. Russell-Smith et all, "Sustainable Target Value Design-Integrating Life Cycle Assessment and Target Value Design to Improve Building Energy and Environmental Performance" (2015) 88 Journal of Cleaner Production 88 (2015): 44.

90 Arijit Sinha, Rakesh Gupta and Andreja Kutnar, Op.cit., 49.
}

89 Ibid, 45.

91 Ibid. 
design. Furthermore, LCA could also be a good way to help green building industries in measuring their actual cost in energy efficiency. In other words, the government should be able to combine between the command and control based regulation and market based regulation, because control and command alone will not be able to support the green building development in Indonesia.

In the case of Jakarta Provincial Decree, there should be revision on the existing green building energy efficiency strategy in Jakarta based on consideration that the criteria applied for new building is more stringent than existing building, while in practice there are a lot of existing building that is operated in traditional way and there is no obligation for the existing buildings to be upgraded as green buildings. Besides, this Governor Decree is only applied to some types of building with certain area and function. In fact, there is no obligation for buildings which the area is below than the area set forth in the Governor Decree.

\section{Reference}

\section{Books}

Asshiddiqie, Jimly and M. Ali Safa'at, Teori Hans Kelsen Tentang (Konpress, Jakarta, 2006).

Attamimi, A. Hamid S., Peranan Keputusan Presiden Republik Indonesia Dalam Penyelenggaraan Pemerintahan Negara : Suatu Studi Analisis Mengenai Keputusan Presiden Yang Berfungsi Pengaturan Dalam Kurun Waktu Pelita I Pelita VI (Disertasi, Pasca Sarjana Universitas Indonesia, 1990).

Baldwin, Robert, Martin Cave and Martin Lodge, Understanding Regulation, Theory, Strategy and Practice (Oxford University Press, $2^{\text {nd }}$ edition, 2012).

Fowler, K.M and E.M Rauch, Assessing Green Building Performance: A Post Occupancy Evaluation of 12 GSA Buildings (Pacific Northwest National Laboratory Report Number PNNL-17393, 2008).
Turner, C., "LEED Building Performance in the Cascadia Region: A Post Occupancy Evaluation Report," (http://www.usgbc.org, 2006).

Wen Hong et all, Building Energy Efficiency, Why Green Building Are Key to Asia

Zimmer, Michael J., and Jennifer M Rohleder, "Green Building Financing" in J. Cullen Howe and Michael B. Gerrarad, The Law of Green Buildings, Regulatory and Legal Issues in Design, Construction, Operations, and Financing (American Bar Association and ELI Press).

\section{Paper/Article/Proceeding/Research}

Abair, Jesse W., "Green Buildings: What It Means To Be "Green" and the Evolution of Green Building Laws." Urban Lawyer no. 40 (3) (2008)

Anastasia, Njo, "The Way to Encourage Green Building in Indonesia" (AsRES International Conference, Kyoto-Japan, 2013).

Garry, Thomas, "Turning Buildings Green: Instruments for Improving the Energy Performance of Existing Buildings" New Zealand Journal of Environmental Law no. 2 (1) (2008).

Glesby, Lauren E., "Fitting The Bill-Proposed Regulatory and Non-regulatory Approaches to Advancing Green Building Technologies" Fordham Environmental Law Review no. 21 (2010).

Kelly, Eileen P., et al., "Managerial and legal Perspective on the Green Building Movement," Journal of Legal, Ethical and Regulatory Issues no. 13 92) (2010).

Kylili, Angeliki and Paris A. Fokaides, "European Smart Cities: The Role of Zero Energy Building" Sustainable Cities and Society no. 15 (2005).

Mochtar, Sahid and Dewi Larasati, "Comparative Study On Green Criteria Development Towards Sustainable Infrastructure In Indonesia" Society For Social Management Systems Internet Journal no. 12 (2001).

Russell-Smith, Sarah V. et al., "Sustainable Target Value Design-Integrating Life Cycle Assessment and Target Value Design to Improve Building Energy and Environmental Performance" Journal of Cleaner Production no. 88 (2015).

Sighn, Amanjeet et al., "Effects of Green Buildings on Employee Health and Productivity," International Journal Low Carbon and Technology no. 3 (2010).

Sinha, Arijit, Rakesh Gupta and Andreja Kutnar, "Sustainable Development and Green Buildings" Drvna Industrija no. 64 (1) (2014). 
Spataru, Catalina et al., "Domestic Energy And Occupancy: A Novel Post-Occupancy Evaluation Study" International Journal of Low Carbon Technologies no. 2 (2010).

Qian, Queena K. and Edwin H.W. Chan, "Government Measures Needed to Promote Building Energy Efficiency (BEE) in China" Facilities no. 28 (11/12) (2010).

Future (Asia Business Council, Hong Kong 2007).

Wedding, G.Christopher. and Douglas CrawfordBrown, "Measuring Site-Level Success In Brownfield Redevelopments: A Focus On Sustainability And Green Building," Journal of Environmental Management no. 85 (2007).

Wiryomartono, Bagoes "Green Building and Sustainable Development Policy in Indonesia since 2004" International Journal of Sustainable Building Technology and Urban Development no. 6 (2) (2015).
Xia, Bao et al., "Green Star Points Obtained by Australian Building Project," Journal of Architectural Engineering (2013).

\section{Legislations}

The Law of Republic of Indonesia Number 23 Year 2014 on Local Government.

The Law of Republic of Indonesia Number 12 Year 2011 on The Establishment of Laws and Regulations.

The Law of Republic of Indonesia Number 28 Year 2002 on Building.

The Regulation of the Minister of Public Works and Public Housing No. 02/PRT/M/2015 on Green Building.

The Governor of Jakarta Decree Number 38 Years 2012 on Green Building. 
"Halaman ini dikosongkan" 